\title{
Influence of the Periodicity of Sinusoidal Boundary Condition on the Unsteady Mixed Convection within a Square Enclosure Using an Ag-Water Nanofluid
}

\author{
Azharul Karim ${ }^{1}$, M. Masum Billah ${ }^{2, *}$, M. T. Talukder Newton ${ }^{2}$ and M. Mustafizur Rahman ${ }^{3}$ \\ 1 Science and Engineering Faculty, Queensland University of Technology, Brisbane 4001, Australia; \\ azharul.karim@qut.edu.au \\ 2 Department of Arts and Sciences, Ahsanullah University of Science and Technology, Dhaka 1208, \\ Bangladesh; newtontalukder5@gmail.com \\ 3 Department of Mathematics, Bangladesh University of Engineering and Technology, Dhaka 1000, \\ Bangladesh; mmustafizurrahman@math.buet.ac.bd \\ * Correspondence: mmb.as@aust.edu or mmb.edu@gmail.com; Tel.: +88-017-154-00423
}

Received: 17 November 2017; Accepted: 14 December 2017; Published: 18 December 2017

\begin{abstract}
A numerical study of the unsteady mixed convection heat transfer characteristics of an $\mathrm{Ag}$-water nanofluid confined within a square shape lid-driven cavity has been carried out. The Galerkin weighted residual of the finite element method has been employed to investigate the effects of the periodicity of sinusoidal boundary condition for a wide range of Grashof numbers $(\mathrm{Gr})\left(10^{5}\right.$ to $10^{7}$ ) with the parametric variation of sinusoidal even and odd frequency, $N$, from 1 to 6 at different instants (for $\tau=0.1$ and 1). It has been observed that both the Grashof number and the sinusoidal even and odd frequency have a significant influence on the streamlines and isotherms inside the cavity. The heat transfer rate enhanced by $90 \%$ from the heated surface as the Grashof number $(\mathrm{Gr})$ increased from $10^{5}$ to $10^{7}$ at sinusoidal frequency $N=1$ and $\tau=1$.
\end{abstract}

Keywords: Ag-water nanofluids; unsteady mixed convection; solid volume fraction; sinusoidal frequency; finite element method

\section{Introduction}

Mixed convection in an enclosure has attracted significant attention from thermal researchers and scientists due to its great importance in numerous thermal engineering applications. Enclosures with simple usual triangular or rectangular geometries have been considered to a prodigious extent as such boundaries are easier to model and the thermal and hydrodynamic flow patterns and rotations are less complex than an enclosure having a complex profile, such as a curly surface. Irregular types of cavities are used in the design of many types of heat exchangers, such as the cooling systems of micro-electronic devices, solar collectors, and food dryers [1,2].

A numerical investigation on mixed convection is extremely difficult as the thermal energy and the momentum equations are coupled together owing to a buoyancy force that creates the mixed convective flow within the domain. This scenario is involved when nanofluids are used in the cavity. In a cavity, there are two regions, namely the interior region and the boundary. For the analogous boundary conditions, these two regions have different flow and thermal characteristics. In the case of nanofluids, this circumstance becomes more troublesome if there are distinctive boundary conditions. Natural convection heat transfer phenomena are of prodigious importance as they have a very extensive range of applications, including in solar collectors, electronic cooling, and the desalination process [3-6].

However, the conventional fluids used for natural convection, such as oil, water, ethylene glycol, and air, have very poor thermal conductivity that cannot fulfill a demand for a high thermal 
conductivity of the fluid. To enhance the thermal conductivity notwithstanding the heat transfer rate, an innovative procedure has been developed recently by mixing nano-sized particles, for example, carbon materials, metal, and metal oxide, in the base fluid [7-9]. Such fluid is known as a nanofluid, which has outstanding performance in thermal conductivity and therefore can address the difficulty of higher heat transfer efficiency [10-17] in contemporary engineering applications.

Numerous numerical studies [18-22] have been performed on the effect of a nanofluid considering that the nanofluid is in a single phase. Researchers have claimed that the heat transfer rate has been enhanced due to an increase in the number of nanoparticles. Kim et al. [23] observed that the thermal conductivity and the shape factor are reduced with an increase in the density and heat capacity of the nanoparticles. In addition, an experimental study [9] confirmed that a copper-water nanofluid improved the heat transfer rate. Hwang et al. [24] theoretically showed that the ratio of the heat transfer coefficient of a nanofluid to that of the base fluid is reduced as the size of the nanoparticles increases. Santra et al. [25] observed that the heat transfer rate decreased with an increase in the number of nanoparticles. Ghanbarpour et al. [26] made an experimental study to examine the performance of a heat pipe's performance using nanofluid. They found that the thermal performance of the heat pipes was enhanced using nanofluids compared to the base fluid.

The shape of the enclosure assumes an imperative part in convection; however, the shape relies upon a viable application. Distinctive sorts of enclosures [27-38] confined with nanofluids have been examined in earlier studies. Yu et al. [39] investigated the impact of nanofluids in a base-heated isosceles triangular enclosure using a transient buoyancy driven condition. Laminar mixed convection in an inclined triangular cavity $[40,41]$ using a $\mathrm{Cu}$-water nanofluid has been performed. The authors claimed that the inclined angle plays an important role for the nanofluids in the heat exchange. Billah et al. [42] examined unsteady buoyancy driven heat transfer improvement of nanofluids in a triangular cavity. Rahman et al. [43] exhibited the impact of a corrugated base surface of a triangular enclosure. Sheremet et al. [44] played out a numerical study on the unsteady free convection heat exchange qualities of a nanofluid restricted to a permeable open wavy cavity. They found that the normal Nusselt and Sherwood numbers diminish with an expansion in the undulation number and that these can be enhanced by means of a fitting tuning of the wavy surface geometry parameters. Rahman et al. [45] conducted a computational study to examine the impacts of carbon nano tube (CNT)-water nanofluids in an enclosure with non-isothermal heating for higher Rayleigh numbers. They demonstrated that there is an ideal incentive for nanofluid volume fraction to control heat exchange, temperature appropriation, and stream field. Wu et al. [46] studied the heat transfer and pulsed flow in a Y-type crossing point channel with two inlets and one outlet utilizing water- $\mathrm{Al}_{2} \mathrm{O}_{3}$ nanofluids. They demonstrated that the utilization of the pulsed flow enhances the Nusselt number, particularly for a huge Reynolds number and a high pulse frequency. Rashidi et al. [47] developed a two-way coupling of the discrete phase model to track the discrete nature of aluminum oxide particles in an obstructed duct with two side-by-side obstacles. The influence of an induced magnetic field on the free convection of an $\mathrm{Al}_{2} \mathrm{O}_{3}$-water nanofluid on a permeable plate by means of the Koo-Kleinstreuer-Li (KKL) model is examined by Sheikholeslami et al. [48].

From the above literature, it is revealed that few investigations have been done for a square enclosure along with a sinusoidal heated base surface. The primary enthusiasm for this examination is to consider the heat exchange attributes inside a square shape enclosed area filled with an Ag-water nanofluid with a sinusoidal heated base surface.

\section{Problem Formulation}

\subsection{Physical Model}

We consider a two-dimensional lid-driven square enclosure of length $\mathrm{L}$ with an Ag-water nanofluids confined in it as depicted in Figure 1. The top horizontal wall is permitted to move with a steady speed $U_{c}$. Likewise, the base surface is kept up at a high temperature $T=T_{c}+$ 
$\left(T_{h}-T_{c}\right) \sin (N \pi x / L)$. Also, the vertical walls are considered to be insulated. The impact of gravity appears in the negative $\mathrm{Y}$ axis.

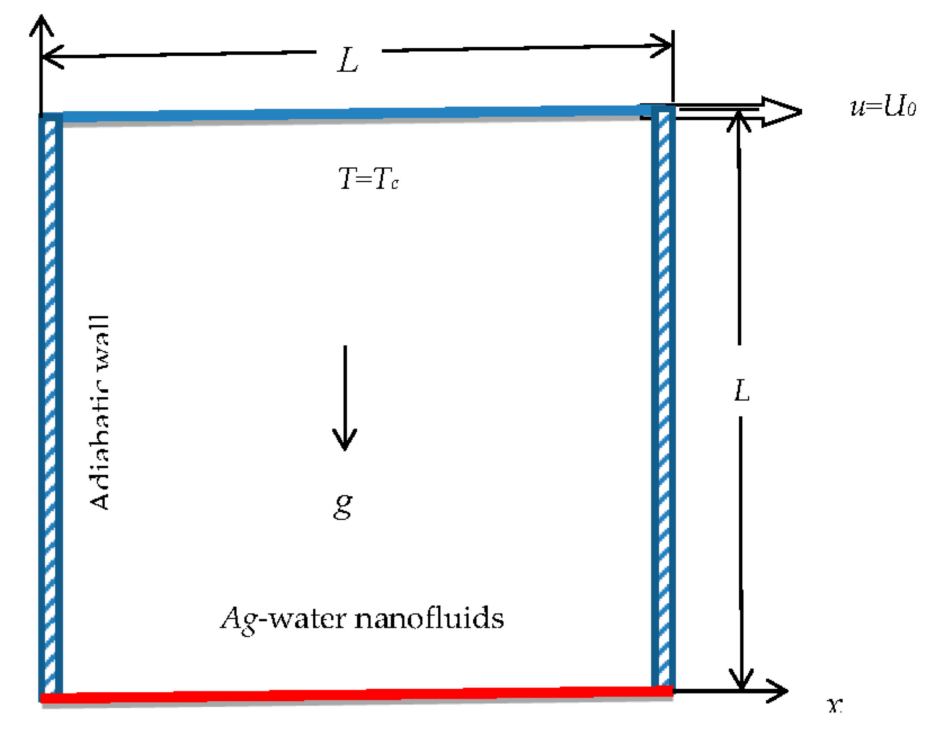

$T=T_{\mathrm{c}}+\left(T_{\mathrm{h}}-T_{\mathrm{c}}\right) \sin (N \pi x / L)$

Figure 1. Schematic view of the cavity with the boundary conditions.

\subsection{Thermophysical Property of the Nanofluid}

For this numerical investigation, Ag is considered to be the nanoparticle and water is selected as the base fluid. Distinctive examinations have been completed by various researchers. The nanoparticles are accepted to have a uniform shape and size. Besides this, it is considered that both the fluid phase and nanoparticles are in a thermal balance state and they flow at a similar speed. In this examination, the thermophysical properties of the nanofluid are thought to be consistent aside from the density variety in the buoyancy force, which depends on the Boussinesq estimation. The information utilized for the numerical investigation is taken from Ahmed et al. [49] and is presented in Table 1.

Table 1. Thermophysical properties of the water and nanoparticle.

\begin{tabular}{ccc}
\hline Properties & Water & Ag \\
\hline$c_{p}\left(\mathrm{~J} \mathrm{Kg}^{-1} \mathrm{~K}^{-1}\right)$ & 4179 & 235 \\
$\rho\left(\mathrm{Kg} \mathrm{m}^{-3}\right)$ & 997.1 & 10,500 \\
$k\left(\mathrm{~W} \mathrm{~m}^{-1} \mathrm{~K}^{-1}\right)$ & 0.613 & 429 \\
$\beta\left(\mathrm{K}^{-1}\right)$ & $2.1 \times 10^{-4}$ & $5.4 \times 10^{-5}$ \\
\hline
\end{tabular}

\subsection{Mathematical Modeling}

The governing equations which describe the framework are the conservation of mass, momentum, and energy equations. The Ag-water nanofluid is filled into the free space of the enclosure which is demonstrated as a Newtonian fluid. The flow is thought to be unsteady, laminar, and incompressible. The thermal balance between the base fluid and the nanoparticles are considered, and no slip conditions between the two media are assumed. In the light of these suppositions, the continuity, momentum, and energy equations [27] in their two-dimensional form can be composed as:

$$
\frac{\partial u}{\partial x}+\frac{\partial v}{\partial y}=0
$$




$$
\begin{gathered}
\frac{\partial u}{\partial t}+u \frac{\partial u}{\partial x}+v \frac{\partial u}{\partial y}=-\frac{1}{\rho_{n f}} \frac{\partial p}{\partial x}+\frac{\mu_{n f}}{\rho_{n f}}\left(\nabla^{2} u\right), \\
\frac{\partial v}{\partial t}+u \frac{\partial v}{\partial x}+v \frac{\partial v}{\partial y}=-\frac{1}{\rho_{n f}} \frac{\partial p}{\partial y}+\frac{\mu_{n f}}{\rho_{n f}}\left(\nabla^{2} v\right)+\frac{(\rho \beta)_{n f}}{\rho_{n f}} g\left(T-T_{c}\right), \\
\frac{\partial T}{\partial t}+u \frac{\partial T}{\partial x}+v \frac{\partial T}{\partial y}=\alpha_{n f}\left(\nabla^{2} T\right),
\end{gathered}
$$

where the effective density $\rho_{n f}$ of then a nanofluid [41] might be characterized by:

$$
\rho_{n f}=\delta \rho_{s}+(1-\delta) \rho_{f}
$$

where $\delta$ is the solid volume fraction of nanoparticles.

In addition, the thermal diffusivity $\alpha_{n f}$ of nanofluids [49] is specified by:

$$
\alpha_{n f}=\frac{k_{n f}}{\left(\rho c_{p}\right)_{n f}}
$$

The heat capacitance of nanofluids [42] may be defined as:

$$
\left(\rho c_{p}\right)_{n f}=\delta\left(\rho c_{p}\right)_{s}+(1-\delta)\left(\rho c_{p}\right)_{f} .
$$

Furthermore, $(\rho \beta)_{n f}$ is the thermal expansion coefficient of the nanofluid and it can be found by:

$$
(\rho \beta)_{n f}=\delta(\rho \beta)_{s}+(1-\delta)(\rho \beta)_{f} .
$$

$\mu_{n f}$ is the dynamic viscosity of the nanofluid introduced by Brinkman [50] as:

$$
\mu_{n f}=\mu_{f} /(1-\delta)^{5 / 2}
$$

The effective thermal conductivity $[18,51]$ of the nanofluidis given as follows:

$$
\frac{k_{n f}}{k_{f}}=\frac{k_{s}+2 k_{f}+2 \delta\left(k_{s}-k_{f}\right)}{k_{s}+2 k_{f}+\delta\left(k_{f}-k_{s}\right)} .
$$

The reasonable initial and boundary conditions in their dimensional shape are:

$$
t=0
$$

For the entire domain:

$$
\begin{gathered}
u=v=0, T=T_{c} \\
t>0, \\
\left.\begin{array}{c}
u=v=0, T=T_{c}+\left(T_{h}-T_{c}\right) \sin (N \pi x / L), \text { for } y=0 \text { and } 0 \leq x \leq L \\
u=U_{0}, v=0, T=T_{c}, \text { for } y=L \text { and } 0 \leq x \leq L \\
u=v=0, \frac{\partial T}{\partial x}=0, \text { for } x=0 \text { and } L \text { and } 0 \leq y \leq L
\end{array}\right\} .
\end{gathered}
$$

Equations (1)-(4) are non dimensionalized using the following dimensionless variables:

$$
X=\frac{x}{L}, Y=\frac{y}{L}, \tau=\frac{U_{0} t}{L}, U=\frac{u}{U_{0}}, V=\frac{v}{U_{0}}, P=\frac{\left(p+\rho_{f} g y\right)}{\rho_{n f} U_{0}^{2}}, \theta=\frac{\left(T-T_{c}\right)}{\left(T_{h}-T_{c}\right)} .
$$


By employing Equation (13), the resulting dimensionless equations are reduced to:

$$
\begin{gathered}
\frac{\partial U}{\partial X}+\frac{\partial V}{\partial Y}=0 \\
\frac{\partial U}{\partial \tau}+U \frac{\partial U}{\partial X}+V \frac{\partial U}{\partial Y}=-\frac{\partial P}{\partial X}+\frac{P r}{\left[\delta\left(\rho_{s} / \rho_{f}\right)+(1-\delta)\right]} \frac{1}{(1-\delta)^{5 / 2}} \nabla^{2} U \\
\frac{\partial V}{\partial \tau}+U \frac{\partial V}{\partial X}+V \frac{\partial V}{\partial Y}=-\frac{\partial P}{\partial Y}+\frac{P r}{\left[\delta\left(\rho_{s} / \rho_{f}\right)+(1-\delta)\right]} \frac{1}{(1-\delta)^{5 / 2}} \nabla^{2} V+\frac{\delta \rho_{s} \beta_{s}+(1-\delta) \rho_{f} \beta_{f}}{\delta \rho_{s} \beta_{f}+(1-\delta) \rho_{f} \beta_{f}} G r P r^{2} \theta \\
\frac{\partial \theta}{\partial \tau}+U \frac{\partial \theta}{\partial X}+V \frac{\partial \theta}{\partial Y}=\frac{(1+2 \delta) k_{s}+2(1-\delta) k_{f}}{(1-\delta) k_{s}+(2+\delta) k_{f}} \frac{1}{(1-\delta)+\delta\left(\left(\rho c_{p}\right)_{s} /\left(\rho c_{p}\right)_{f}\right)} \nabla^{2} \theta
\end{gathered}
$$

Here, the Prandtl number is defined as:

$$
\operatorname{Pr}=v_{f} / \alpha_{f} .
$$

The Grashof number is expressed as:

$$
G r=\frac{g \beta_{f} L^{3}\left(T_{h}-T_{c}\right)}{v_{f}^{2}} .
$$

The overall Nusselt number at the heated surface of the enclosure can be expressed by:

$$
N u_{a v}=-\frac{k_{n f}}{k_{f}} \int_{0}^{L} \frac{\partial \theta}{\partial Y} d X .
$$

The fluid motion is displayed by means of the stream function $\psi$ acquired from velocity components $U$ and $V$. The relationships among the stream function and velocity components [52] for two-dimensional flows are:

$$
U=\frac{\partial \psi}{\partial Y}, V=-\frac{\partial \psi}{\partial X} .
$$

\section{Solution Procedure}

\subsection{Numerical Scheme}

The initial and boundary conditions for the governing Equations (15)-(17) are described below. The initial and boundary conditions in the dimensionless frame for the present issues for $\tau=0$.

The condition of the entire domain:

$$
U=V=0, \theta=0,
$$

and for $\tau>0$,

$$
\left.\begin{array}{c}
U=V=0, \theta=\sin (N \pi X), \text { for } Y=0 \text { and } 0 \leq X \leq 1 \\
U=1, V=0, \theta=0, \text { for } Y=1 \text { and } 0 \leq X \leq 1 \\
U=V=0, \frac{\partial \theta}{\partial X}=0, \text { for } X=0 \text { and } 1 \text { and } 0 \leq Y \leq 1
\end{array}\right\}
$$

The equations are solved by employing the Finite element method, and the Galerkin weighted residual technique is employed to discretize the equations. Details about this discretization method can be found in [42]. A non-uniform triangular component is to be found over the enclosed area. For every component, the required factors are processed utilizing an interpolation technique. An arrangement of algebraic equations has been framed by the representing condition "decrease the continuum territory into the discrete triangular region". Later on, the algebraic equations are solved utilizing Newton's 
iteration technique. The convergence criteria for successive solutions are fixed such that the relative error for each variable between consecutive iterations is computed below the performed value of $\varepsilon$ as:

$$
\left|\frac{\Gamma^{m+1}-\Gamma^{m}}{\Gamma^{m+1}}\right|<\varepsilon,
$$

where $m$ is Newton's iteration index and $\Gamma$ is the general dependent variable. The value of $\varepsilon$ is set to be $10^{-5}$.

\subsection{Grid Independency Test}

A grid independency appraisal has been performed for this model and the outcome appears in Figure 2. The grid independency assessment has been done for $\delta=0.4, N=1$, and Grashof number $\mathrm{Gr}=10^{7}$ for the Ag-water nanofluids. The components' numbers differ for the four indicated conditions. The element numbers are $2496,3588,4844$, and 6186 . It has been discovered that overall, the Nusselt number is more noteworthy for the grid of element number 2496. So, the investigation has been performed for this grid of element number 2496.

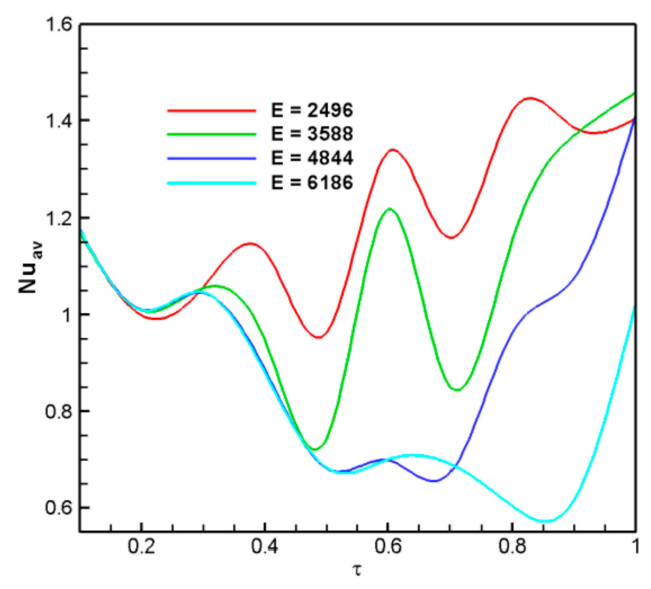

Figure 2. Grid independency study with $\delta=0.04, N=1$, and $G r=10^{7}$.

\subsection{Validationof the Code and Numerical Scheme}

The present numerical investigation has been validated with the published work. Code approval was finished with a view to checking the exactness of the numerical solution and the arrangement methodology of the issue. The current investigation was compared with Khanafer et al. [18] with $\delta=0.04$ and $10^{3} \leq G r \leq 10^{5}$ on the premise of the overall Nusselt number, and the deviation with the investigation is accounted for in Table 2. From the table, it is clear that the present code and the numerical scheme are totally reliable as they demonstrate great concurrence with the earlier published work. The present investigation differs not over $3 \%$ with the past one.

Table 2. Comparison of $N u_{a v}$ with $\delta=0.04$ with those of Khanafer et al. [18].

\begin{tabular}{cccc}
\hline \multirow{2}{*}{$\boldsymbol{G} r$} & \multicolumn{3}{c}{$N u_{a v}$} \\
\cline { 2 - 4 } & Ref. [18] & Present Study & Error (\%) \\
\hline $10^{3}$ & 2.1182 & 2.0898 & 1.34 \\
$10^{4}$ & 4.3478 & 4.3399 & 0.18 \\
$10^{5}$ & 8.9243 & 8.7351 & 2.12 \\
\hline
\end{tabular}




\section{Results and Discussion}

In this article, a time-dependent solution is adopted for the subsequent differential conditions utilizing a finite element analysis. The consequences of this investigation are analyzed for the scope of Grashof numbers, $\mathrm{Gr}$ from $10^{5}$ to $10^{7}$, with a parametric variety of sinusoidal even and odd frequency, $N$ from 1 to 6 , at various instances (for $\tau=0.1$ and 1 ). For the other governing parameters, the Prandtl number $(\operatorname{Pr})$ is settled at 6.2 and the solid volume fraction $\delta$ is set at 0.04 . The subsequent stream and thermal structures are broken down to provide an understanding of the instrument behind the impact of the Grashof number, corrugation frequency, and instances on the stream and thermal fields and the enhancement of heat transfer. The essential non-dimensional parameters of enthusiasm for the present investigation are the local and average Nusselt numbers, which were inspected to reach the significant outcome of the present study.

\subsection{Effect of Even and Odd Frequencies on Streamlines Varying the Dimensionless Time}

In Figure 3, the effect of the odd frequency $N(=1,3,5)$ on streamlines has been presented at $G r=10^{5}$ for the preferred values of $\tau$. For $\tau=0.1$, the effect of the odd values of $N$ is depicted in the left column. At $N=1$ and $\tau=0.1$, two primary opposite rotating vortices are formed near the bottom surface with an incredibly low value of stream function, indicating poor convective heat transfer. From this figure, it can be observed that $\psi_{\max }=0.3$ and $\psi_{\min }=-0.3$. Further, two reverse rotating vortices with the same flow strength are created near the vicinity of the vertical walls. Cells are framed in a symmetric way, indicating the exceptionally ordinary nature of convection. Here, the liquid takes up heat energy from the base-heated wall and ends up plainly lighter to invigorate a convective current. Lighter liquid goes up, and because of the symmetric idea of a colder wall, the colder bit of liquid takes after the line followed by the colder walls. As a result, symmetric cells are acquired. However, at $N=3$ and $\tau=0.1$, the essential inverse pivoting cells rule and cover the entire space. This is why the two reverse-rotating vortices near the vertical walls disappear. For $N=5$, four cells are split instead of two; the dominating cells in the interior have a reverse sense of rotation. At the bottom wall, a couple of minor vortices are twisted. On the other hand, for $\tau=1$, a similar pattern on the effect of the odd values of $N$ is shown in the right column.
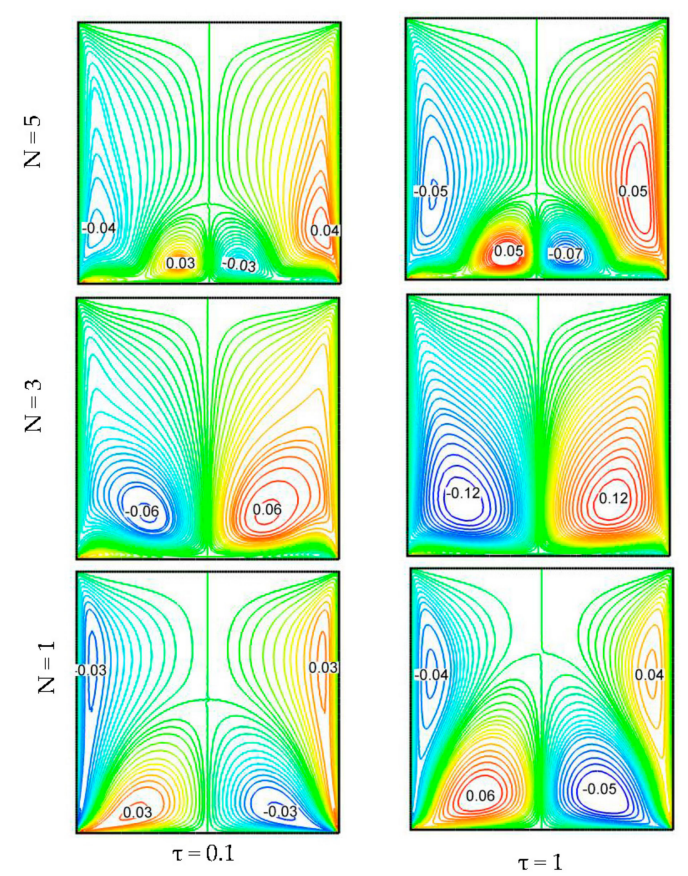

Figure 3. Influence of the odd values of $N$ on streamlines for the selected values of $\tau$ with $G r=10^{5}$. 
The influence of the even frequencies $N(=2,4,6)$ on streamlines at $G r=10^{5}$ of the preferred values of $\tau$ is depicted in Figure 4. For $\tau=0.1$, the effect of the even values of $N$ is shown in the left column. At $N=2$ and $\tau=0.1$, a major rotating eddy is formed near the bottom surface which covers nearly the major space of the domain. Two very smaller vortices are found at the corner of the bottom wall. An elliptic shape vortex is seen at the surrounding area of the right vertical surface. At $N=4$, there are four cells having an opposite sense of rotation. However, in the case of $N=6$, this symmetry is entirely conked out and a very strong convective current outline is produced. Five cells are formed, and four are near the sinusoidal heated bottom surface having low to moderate strength. In contrast, for $\tau=1$ and $N=2$, there are two cells instead of four, with the commanding cells in the center having a reverse sense of revolution. The commanding cell is at the heart of the square cavity; it has a stream function value of -0.34 and is revolving in the clockwise direction.
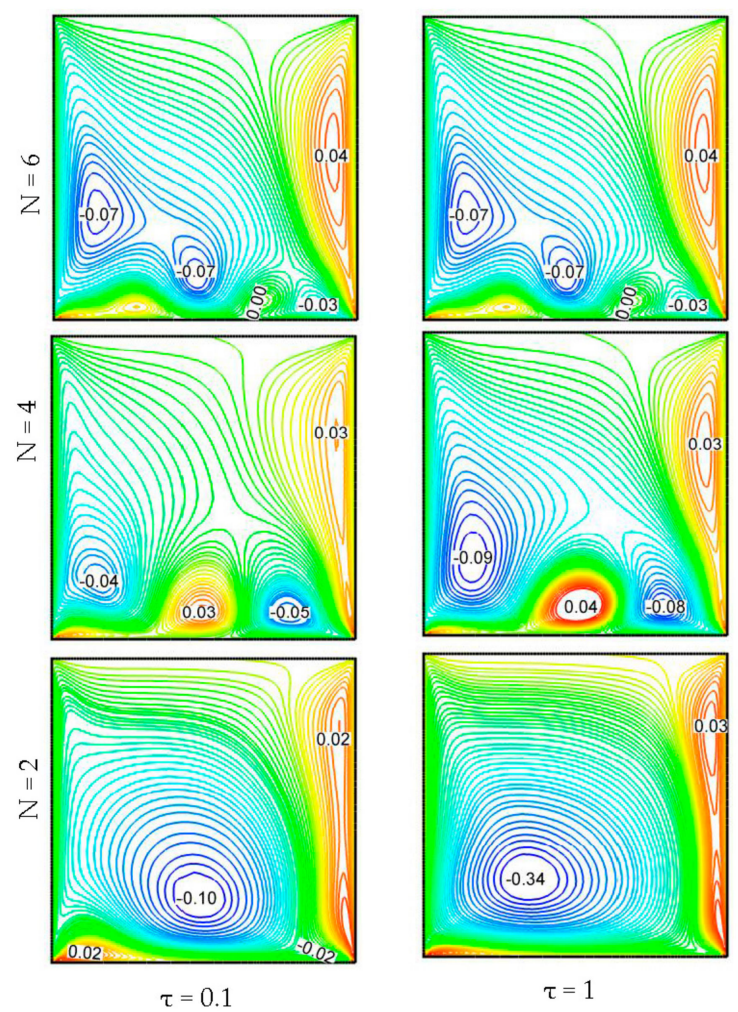

Figure 4. Influence of the even values of $N$ on streamlines for the selected values of $\tau$ with $G r=10^{5}$.

The effects of odd frequencies $N(=1,3,5)$ on streamlines at $G r=10^{6}$ for the chosen values of $\tau$ are shown in Figure 5. For $N=1$ and $\tau=0.1$, two key opposite rotating vortices are produced near the bottom face with a very low value of stream function, indicating a meager convective heat transfer. It is clearly seen that $\psi_{\max }=0.4$ and $\psi_{\min }=-0.5$. The other two opposite rotating vortices with the same flow strength are formed near the vicinity of the upright walls. However, the primary opposite rotating cells at $N=3$ and $\tau=0.1$ dominate and enclose the whole domain. As a consequence, the two reverse rotating vortices near the vertical walls are moved out. In this cell, the highest value of the stream function is observed to be $\psi_{\max }=0.11$ and the smallest value is observed to be $\psi_{\min }=-0.10$. However, at $N=5$, four cells are split instead of two, and the dominating cells in the interior have a reverse sense of rotation. Since the bottom wall induced heat energy into the fluid, the convective currents are more adjoining to the base-heated surface. Generally, the flow at $N=5$ indicates very good convective characteristics. In contrast, for $\tau=1$, an analogous pattern on the effect of the odd values of $N$ is shown in the right column. While it compares with the rotating cells at $\tau=1$, both the opposite rotating vortices are bigger in size near the bottom surface than at $\tau=0.1$. In this cell, 
the maximum value of the stream function is assumed to be $\psi_{\max }=0.16$ and the minimum value of the stream function is $\psi_{\min }=-0.16$. If we compare the primary opposite rotating cells at $N=3$ and $\tau=1$ with $\tau=0.1$, it is found that the flow strength is almost doubled. It is clearly observed that the maximum value of the stream function is $\psi_{\max }=0.22$ and the minimum value is $\psi_{\min }=-0.22$.
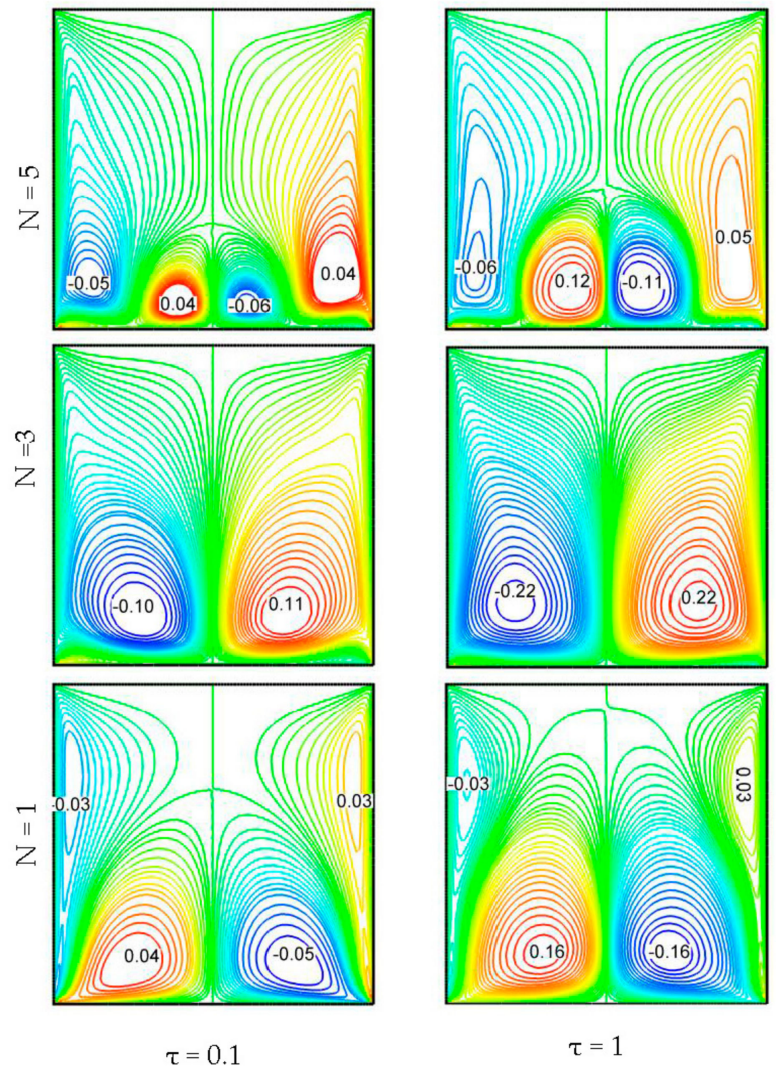

Figure 5. Influence of the odd values of $N$ on streamlines for the selected values of $\tau$ with $G r=10^{6}$.

The influence of the even frequencies $N(=2,4,6)$ on streamlines at $G r=10^{6}$ for some values of $\tau$ is displayed in Figure 6. For $N=2$ and $\tau=0.1$, a most important rotating vortex is created near the bottom surface which covers almost the major space of the domain; it has a stream function value of 0.20 and a negative sense of rotation. Two very smaller vortices are found at the left corner of the bottom wall and at the top of the right vertical wall. At $N=4$ and $\tau=0.1$, there are four cells having an opposite sense of rotation. However, in the case of $N=6$, a mighty convective current outline is produced. Six vortices are created, among which five are in the vicinity of the sinusoidal heated base surface and have low to moderate strength. It is without a doubt observed that the convective streams are all the more connecting to the base-heated wall for an observable reason and that is that from this wall heat stream is approaching into the fluid. By and large, a decent convective attribute appears by the stream at $N=6$ and $\tau=0.1$. However, for $\tau=1$ and $N=2$, there are two cells rather than three, and the ruling cells in the center have an inverse feeling of turn. The commanding cell is at the center of the square walled-in area, has a stream function estimation of -0.91 , and is turning in a clockwise way; however, for $N=4$ and $\tau=1$, there are four cells that have an inverse feeling of rotation. Then again, if there should arise an occurrence of $N=6$ and $\tau=1$, an amazingly strong convective current sample is generated. In this case, six cells are framed, where three are in the proximity of the sinusoidal heated base surface with low to moderate strength. 

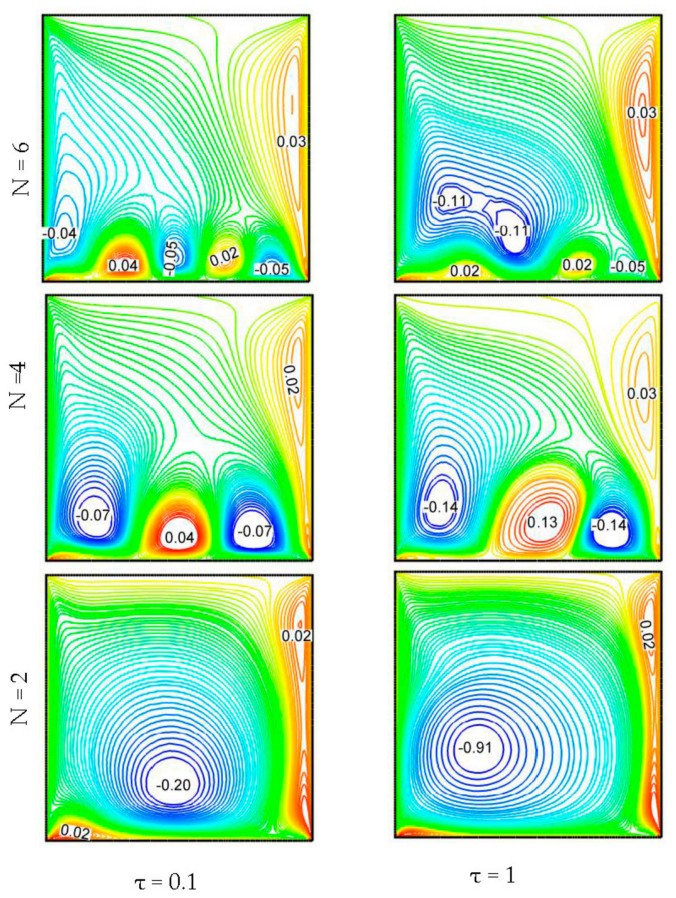

Figure 6. Influence of the even values of $N$ on streamlines for the selected values of $\tau$ with $G r=10^{6}$.

The result of the odd frequencies $N(=1,3,5)$ on streamlines at $G r=10^{7}$ for the different values of $\tau$ is revealed in Figure 7. For $N=1$ and $\tau=0.1$, a more mightier stream pattern is accomplished with four cells shaped in a symmetric way. In general, a decisive change in convection is seen just by expanding the estimation of $N$. If there should arise an occurrence of $N=3$ and $\tau=0.1$, the strongest stream pattern is found, with two noteworthy rotating cells framed in a symmetric approach having $\psi_{\max }=0.87$ and $\psi_{\min }=-0.93$. Yet, there is a fascinating example of progress in the estimation of the streamline on account of $\tau=0.1$ for a fluctuating $N$. Here, four cells are shaped close to the base-heated surface of the cavity with a very strong flow strength $\left(\psi_{\max }=0.34\right.$ and $\left.\psi_{\min }=-0.38\right)$. The convective streams are more nearby the base-heated surface for a clear reason, and that is that from this wall heat energy is going into the fluid. Then again, if there should arise an occurrence of $\tau=1$ and $N=1$, the symmetry is totally broken, and a very strong convective current pattern is created. Here, five cells are framed, four at each of the four corners with a low to moderate strength. The ruling cell is at the center of the rectangular corner, with a stream function estimation of 7.50 and positive sense of rotation. In any case, the overall convective current pattern recommends that the convective heat motion is more mightier in instances of $N=5$ and $\tau=1$ than $N=1$ at $\tau=1$.

Figure 8 gives the effect of the even frequencies $N(=2,4,6)$ on streamlines at $G r=10^{7}$ for some values of $\tau$. For $N=2$ and $\tau=0.1$, a dominating rotating vortex is created near the bottom surface, which covered approximately the major part of the domain and has a stream function value of -1.96 . Three very smaller vortices are found at three corners of the cavity. For $N=4$ and $\tau=0.1$, four cells are formed, where three are in the vicinity of the sinusoidal heated foot surface with a lower to fair strength. However, in the case of $N=6$, a very strong convective current outline is created. In this case, six cells are framed, where five are in the vicinity of the sinusoidal heated base surface with a low to moderate strength. An interesting flow pattern can be noticed in the right column of Figure 8 . The overall convective current outline recommends that the convective heat transfer is strongest for $N=6$ and $\tau=1$. 

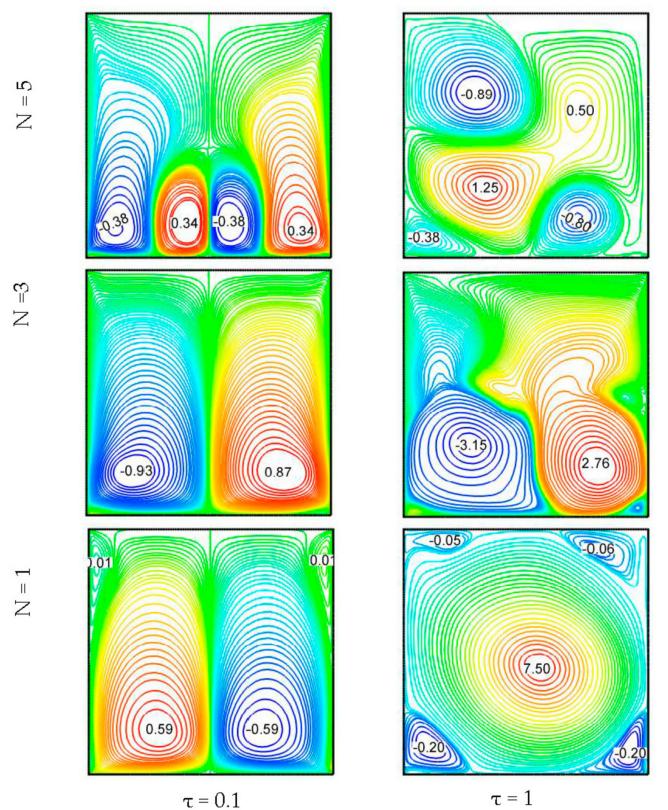

Figure 7. Influence of the odd values of $N$ on streamlines for the selected values of $\tau$ with $G r=10^{7}$.
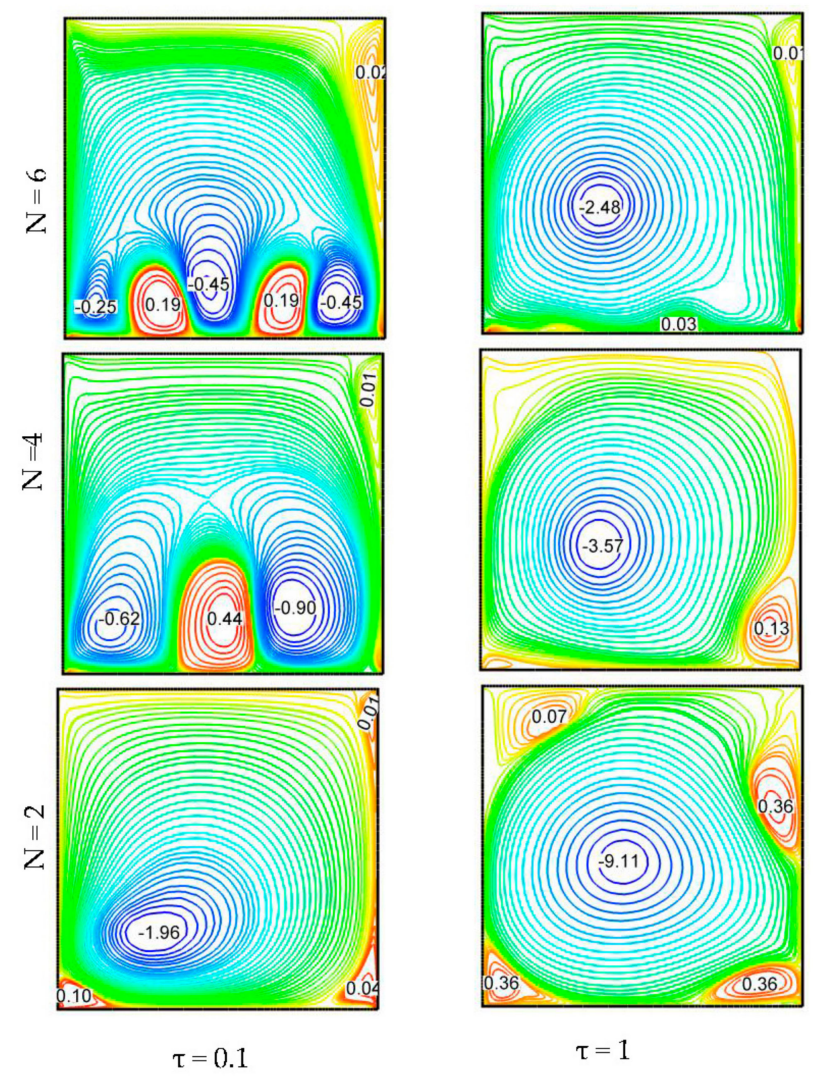

Figure 8. Influence of the even values of $N$ on streamlines for the selected values of $\tau$ with $G r=10^{7}$.

\subsection{Effect of Even and Odd Frequencies on Isotherms Varying Dimensionless Time}

In Figure 9, the consequence of varying odd frequency $N(=1,3,5)$ on isotherms is shown for different values of $\tau(=0.1$ and 1$)$ for $G r=10^{5}$. For $N=1$, the isotherms near the top leading horizontal wall are parallel to each other. The parallel concept of isotherms indicates the control of conductive heat transfer; however, near the bottom sinusoidal heated face the isotherms are semi-elliptic and 
densely distributed for both situations $\tau=0.1$ and 1 . For $N=3$, the isotherms are found to be compactly packed along the bottom surface and very thickly packed at the sinusoidal heated bottom wall for $N=5$. It confirms that convection is very mighty in those areas. As a consequence, the temperature gradient is lower near the top wall for both cases $\tau=0.1$ and 1 .
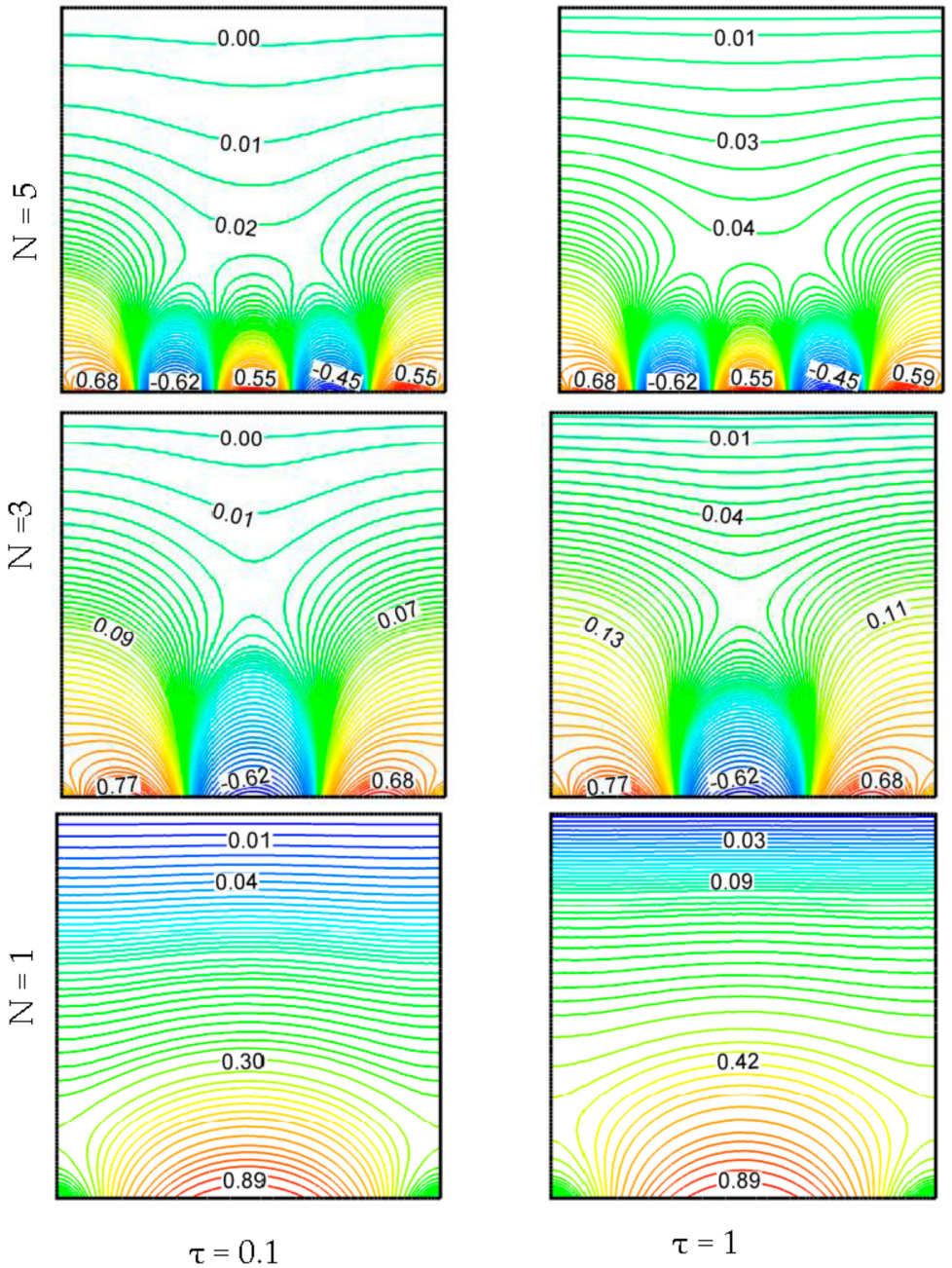

Figure 9. Influence of the odd values of $N$ on isotherms for the selected values of $\tau$ with $G r=10^{5}$.

The results of varying even frequency $N(=2,4,6)$ on isotherms for different values of $\tau(=0.1$ and 1) is depicted in Figure 10 for $G r=10^{5}$. For $N=2$, the isotherms assume a coconut tree leaf shape showing the presence of convective heat transfer in both cases of $\tau(=0.1$ and 1$)$. It can clearly be seen that the isotherm pattern is symmetrical about the mid-vertical plane for the lower value of $\tau(=0.1)$, which demonstrates that our explanation held for the argumentation on the streamlines' distribution. For $N=4$, finger print shape isotherms are found to be thickly stacked along the bottom surface and very thickly stacked near the sinusoidal heated bottom wall for $N=6$. It gives that the convection is very strong in the bottom heated region. As an outcome, the temperature gradient is lower near the middle part of the top segment of the enclosure for both cases $\tau=0.1$ and 1 . 

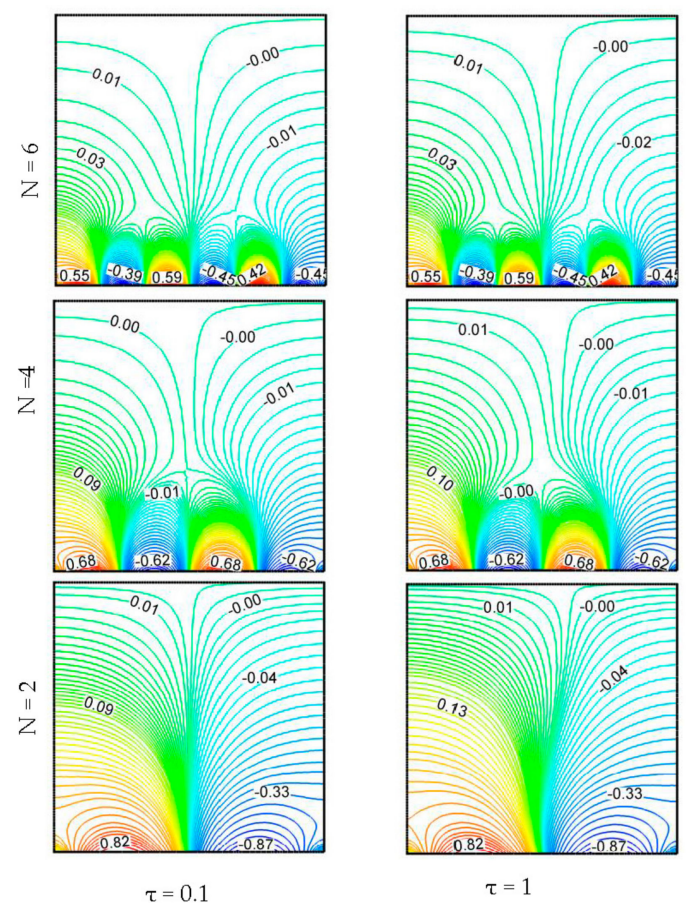

Figure 10. Influence of the even values of $N$ on isotherms for the selected values of $\tau$ with $G r=10^{5}$.

The outcome of varying odd frequency $N(=1,3,5)$ on isotherms for different values of $\tau(=0.1$ and 1$)$ is foreshadowed in Figure 11 for $G r=10^{6}$. For $N=1$, the lower-value isothermal lines are found near the top leading horizontal wall and are parallel to each other. This parallel attribute of the isotherms provides for the control of conductive heat transfer; however, near the bottom sinusoidal heated face, the isotherms are semi-elliptic and densely distributed for both situations $\tau=0.1$ and 1. For $N=3$, the isotherms are seen to be tightly crowded in the vicinity of the bottom surface, and are very tightly packed at the sinusoidal heated bottom wall for $N=5$. At the upper segment of the enclosure, the isotherms are distorted. As a result, the temperature gradient is lower near the top wall for both cases $\tau=0.1$ and 1. It proves our remarks in the argumentation on the streamlines' distribution.

The effects of even frequency $N(=2,4,6)$ on isotherms for different values of $\tau(=0.1$ and 1$)$ are shown in Figure 12 for $\mathrm{Gr}=10^{6}$. The isothermal pattern is similar to that derived from the procedure defined in the earlier even frequency passages with respect to the time variable. No noticeable variation is found in the distribution of isotherms in the case $\tau=0.1$ for each of the even frequencies of $\mathrm{N}$, even though for $\tau=1$, at smaller values of $N$, strong existence of conduction is found inside the cavity. Since the estimation of $G r$ is enlarged, both heat transfer modes appear to be more efficient.

Figure 13 displays the influence of odd frequency $N(=1,3,5)$ on isotherms for different values of $\tau$ (=0.1 and 1) for $\mathrm{Gr}=10^{7}$. This process continues that portrayed in the earlier odd frequency passages with respect to the time variable. Despite the fact that for $\tau=1$, at smaller values of $\mathrm{N}$, there is mighty existence of conduction inside the cavity, there is no recognizable variation in the isotherms' distribution in the case $\tau=0.1$ for each of the odd frequencies of $\mathrm{N}$. Moreover, whenever the estimation of $G r$ is improved, both the heat transfer modes appear to be effective.

The effects of even frequency $N(=2,4,6)$ on isotherms for different values of $\tau(=0.1$ and 1$)$ are displayed in Figure 14 for $G r=10^{7}$. At $N=2$, the isotherm patterns are similar to a coconut tree leaf shape, showing the presence of convective heat transfer for $\tau=0.1$. For $N=4$, finger print shape isotherms are found to be tightly crowded along the bottom heated surface, and areabundantly thickly packed at the sinusoidal heated bottom wall for $N=6$. It is found that convection is incredibly strong in the bottom heated region. 

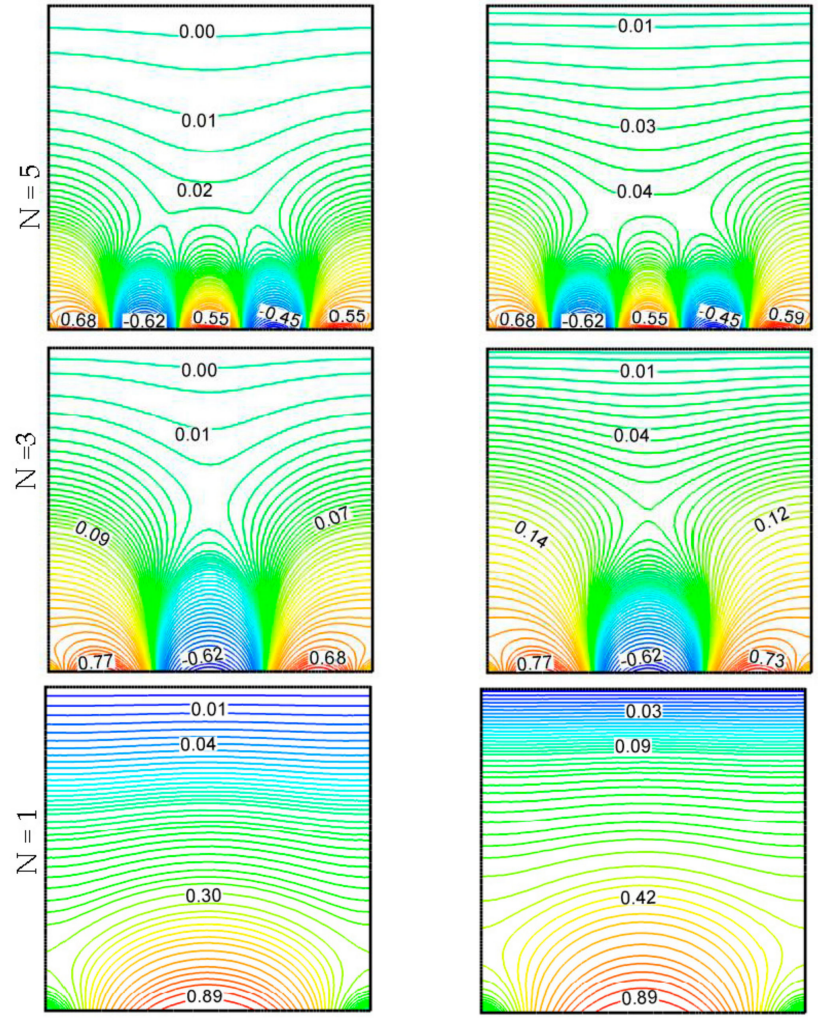

$\tau=0.1$

$\tau=1$

Figure 11. Influence of the odd values of $N$ on isotherms for the selected values of $\tau$ with $G r=10^{6}$.
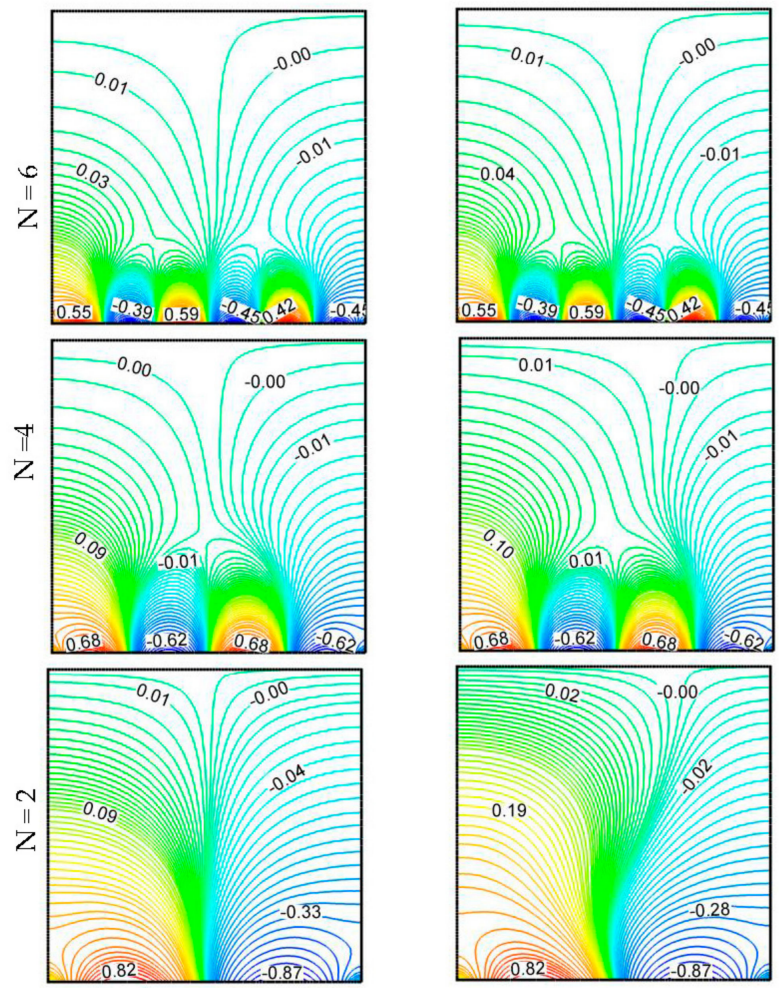

$\tau=0.1$

$\tau=1$

Figure 12. Influence of the even values of $N$ on isotherms for the selected values of $\tau$ with $G r=10^{6}$. 

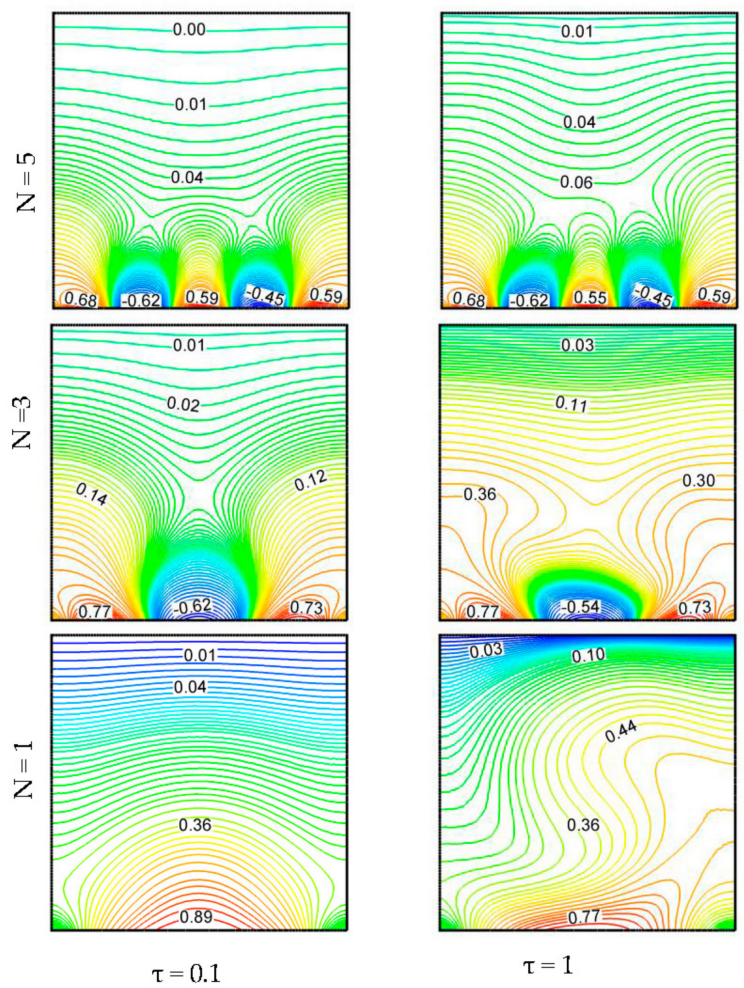

Figure 13. Influence of the odd values of $N$ on isotherms for the selected values of $\tau$ with $G r=10^{7}$.
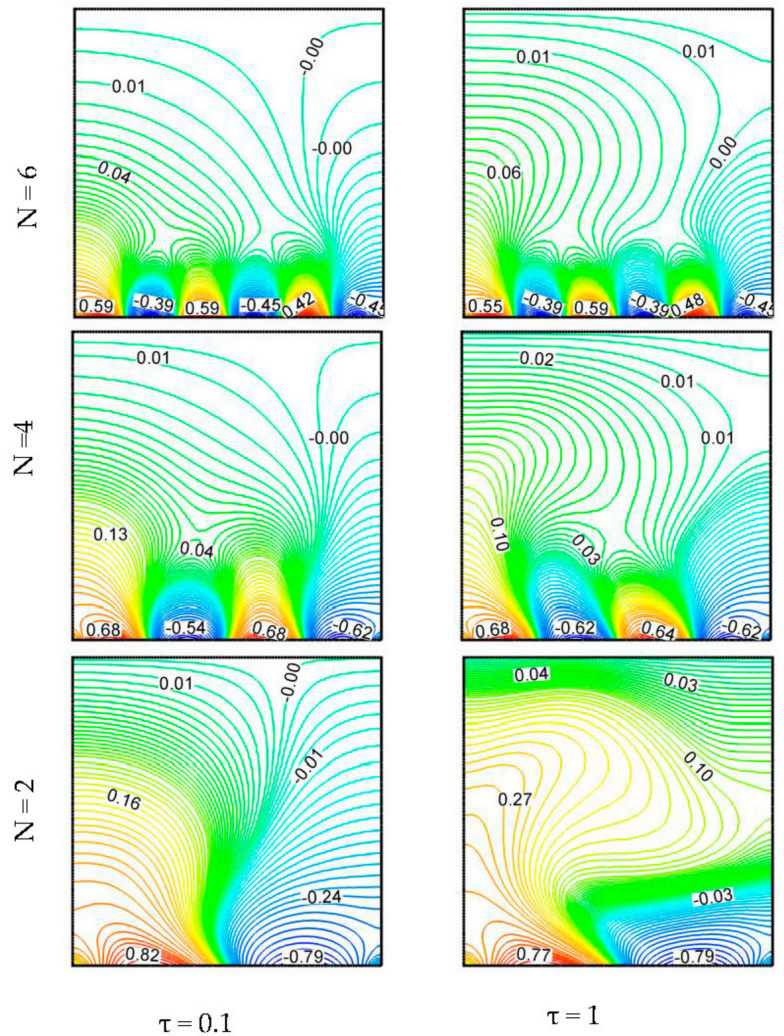

Figure 14. Influence of the even values of $N$ on isotherms for the selected values of $\tau$ with $G r=10^{7}$. 


\subsection{Effect of Different Frequencies on Local Nusselt Number}

Figure 15 illustrates the variation in local Nusselt number for odd and even frequencies $\mathrm{N}$. In each case, it is noticed that for the estimation of $\mathrm{Gr}=10^{7}$, the magnitude of the local Nusselt number is extremum. These results show that convection heat transfer appears to be mightier at a higher value of $G r$ and a higher frequency.

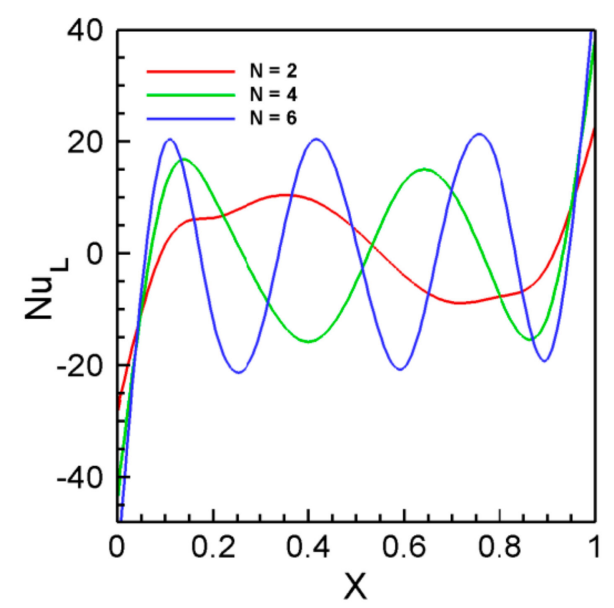

(a)

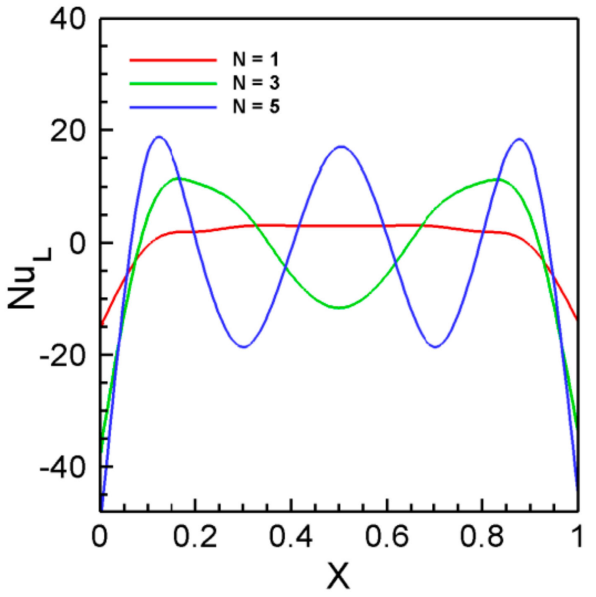

(b)

Figure 15. Variation of the local Nusselt number for (a) even values of $N$ and (b) odd values of $N$, when $\mathrm{Gr}=10^{7}$ and $\tau=1$.

\subsection{Effect of Different Frequencies on Overall Nusselt Number for Different Grs}

In Figure 16, the variation in overall Nusselt number with changing instants in comparison to the odd and even frequencies $N$ for different $G r$ has been represented. Figure 16a shows the effects of odd frequency $N$ for three different Grashof numbers $\left(\mathrm{Gr}=10^{5}, 10^{6}\right.$, and $\left.10^{7}\right)$. For all cases, it is observed that for $N=1$, the magnitude of the overall Nusselt number is supremum. The estimation of the overall Nusselt number rises for all values of $G r$ with a decreasing odd frequency $N$. These results give the connotation that convective heat transfer appears to be mightier at a larger estimation of $G r$ and a lower value of odd frequency, which strongly proves our remarks made during the argumentation on the streamlines' and isotherms' distribution. However, Figure 16b depicts the effects of even frequency $N$ for three different Grashof numbers $\left(G r=10^{5}, 10^{6}\right.$, and $\left.10^{7}\right)$. It is also noticed that for $N=2$, the value of the overall Nusselt number is supremum for all cases. The estimation of the overall Nusselt number grows for all estimations of $G r$ with a decreasing even frequency $N$. However, it can be noticed that the maximum average heat transfer rate occurred for a larger value of $G r$ with a smaller value of $N$.
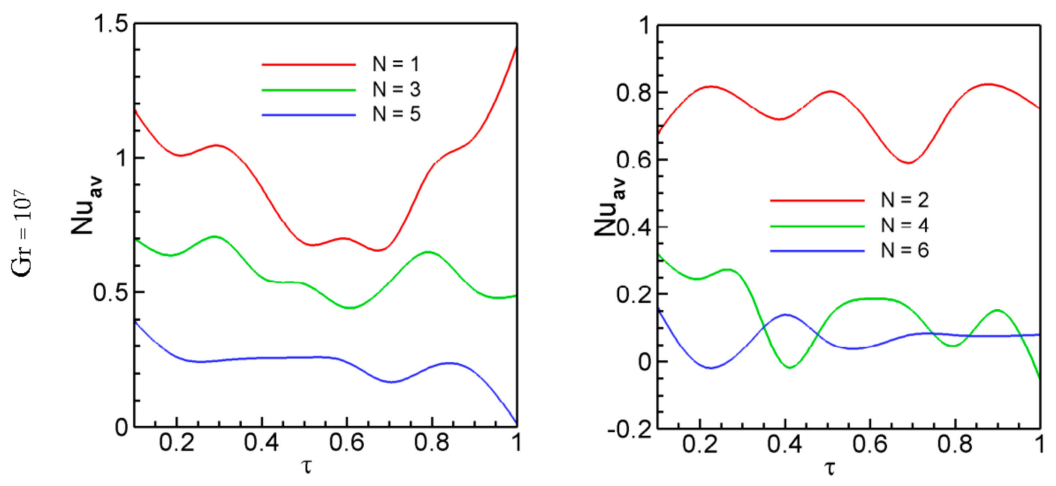

Figure 16. Cont. 

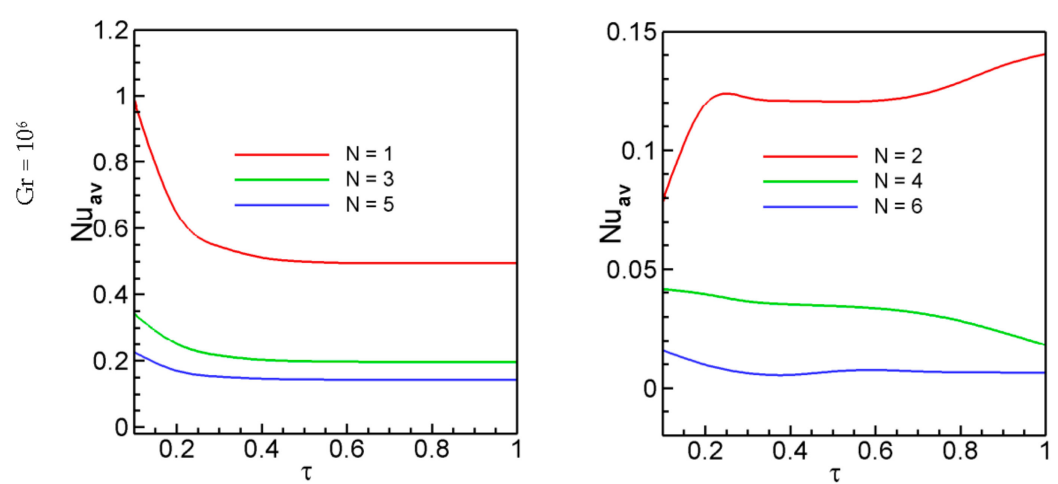

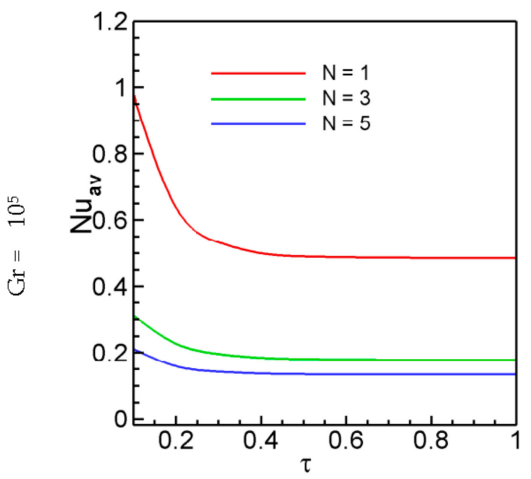

(a)

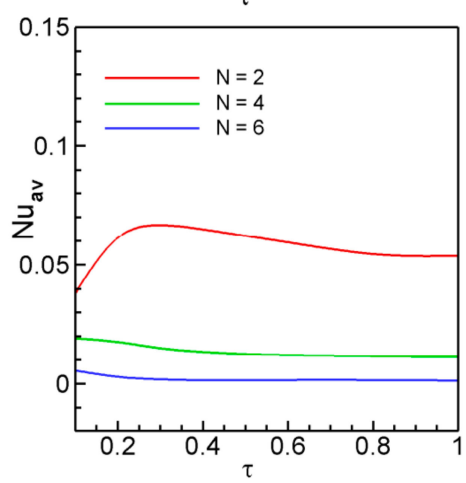

(b)

Figure 16. Variation of the overall Nusselt number for (a) odd values of $N$ and (b) even values of $N$.

\subsection{Correlation of Overall Nusselt Number for Different Frequencies and Different Grs}

In the current study, the correlation of overall Nusselt number $N u_{a v}$ for $N$ and $G r$ has been found as follows:

For even frequency $N$ :

$$
N u_{a v}=0.0004 G r-0.0509 N+0.2082 .
$$

For odd frequency $N$ :

$$
N u_{a v}=0.0003 \mathrm{Gr}-0.1921 N+1.0647 .
$$

\section{Conclusions}

In the present study, Ag-water nanofluids confined within a lid-driven square cavity with a sinusoidal heated bottom surface were solved numerically. The numerical results are explained, and from the investigation the subsequent points may be drawn:

- When the solid volume fraction is retained at 0.04 , the convective heat transfer execution is improved.

- Improving the $G r$ number is adequate to raise the convective heat transfer successfully.

- At larger estimations of $G r$, convection is exceptionally strong for lower estimations of frequencies for both even and odd values of $\mathrm{N}$.

- For smaller estimations of $\mathrm{Gr}$, conduction is the primitive mode of heat transfer.

- A higher value of $G r$ and lower values of $N$ supports enhanced heat transfer through convection and conduction.

- The overall Nusselt number at the heated surface rises with an increasing estimation of $G r$.

The heat transfer rate improved up to $90 \%$ from the heated wall as the Grashof number $(\mathrm{Gr})$ increased from $10^{5}$ to $10^{7}$ for a low odd frequency at $\tau=1$. 
Future studies may consider experimental investigations and compare their results with the simulation results of this study. Such a comparison will provide further validation of the numerical model developed in this study.

Acknowledgments: This study is supported by Queensland University of Technology, 2 George Street, QLD 4001 AUSTRALIA.

Author Contributions: Azharul Karim and M. Masum Billah performed the modeling; M. Mustafizur Rahman analyzed the numerical data; and M. Masum Billah and M. T. Talukder Newton contributed to the initial drafting of the paper.

Conflicts of Interest: The authors declare no conflict of interest.

\section{Nomenclature}

\begin{tabular}{|c|c|}
\hline$c_{p}$ & specific heat $\left(\mathrm{J} \mathrm{kg}^{-1} \mathrm{k}^{-1}\right)$ \\
\hline$g$ & gravitational acceleration $\left(\mathrm{m} \mathrm{s}^{-2}\right)$ \\
\hline Gr & Grashof number \\
\hline$k$ & thermal conductivity $\left(\mathrm{W} \mathrm{m}^{-1} \mathrm{k}^{-1}\right)$ \\
\hline$L$ & length of the enclosure (m) \\
\hline$N u$ & Nusselt number \\
\hline$p$ & dimensional pressure $\left(\mathrm{kg} \mathrm{m}^{-1} \mathrm{~s}^{-2}\right)$ \\
\hline$P$ & dimensionless pressure \\
\hline $\operatorname{Pr}$ & Prandtl number \\
\hline$T$ & fluid temperature $(\mathrm{K})$ \\
\hline$t$ & dimensional time (s) \\
\hline$u$ & horizontal velocity component $\left(\mathrm{m} \mathrm{s}^{-1}\right)$ \\
\hline$U$ & dimensionless horizontal velocity component \\
\hline$v$ & vertical velocity component $\left(\mathrm{m} \mathrm{s}^{-1}\right)$ \\
\hline$V$ & dimensionless vertical velocity component \\
\hline$x$ & horizontal coordinate $(\mathrm{m})$ \\
\hline$X$ & dimensionless horizontal coordinate \\
\hline$y$ & vertical coordínate $(m)$ \\
\hline$Y$ & dimensionless vertical coordinate \\
\hline$k$ & thermal conductivity $\left(\mathrm{W} \mathrm{m}^{-1} \mathrm{k}^{-1}\right)$ \\
\hline \multicolumn{2}{|c|}{ Greek Symbols } \\
\hline$\alpha$ & thermal diffusivity $\left(\mathrm{m}^{2} \mathrm{~s}^{-1}\right)$ \\
\hline$\beta$ & thermal expansion coefficient $\left(\mathrm{K}^{-1}\right)$ \\
\hline$\delta$ & solid volume fraction \\
\hline$\mu$ & dynamic viscosity $\left(\mathrm{kg} \mathrm{m}^{-1} \mathrm{~s}^{-1}\right)$ \\
\hline$v$ & kinematic viscosity $\left(\mathrm{m}^{2} \mathrm{~s}^{-1}\right)$ \\
\hline$\tau$ & dimensionless time \\
\hline$\theta$ & non-dimensional temperature \\
\hline$\rho$ & density $\left(\mathrm{kg} \mathrm{m}^{-3}\right)$ \\
\hline$\psi$ & stream function \\
\hline$\lambda$ & wave length \\
\hline$\Gamma$ & general dependent variable \\
\hline \multicolumn{2}{|c|}{ Subscripts } \\
\hline$a v$ & average \\
\hline$h$ & hot \\
\hline$c$ & cold \\
\hline $\mathrm{f}$ & fluid \\
\hline $\mathrm{nf}$ & nanofluid \\
\hline $\mathrm{s}$ & solid nanoparticle \\
\hline $\max$ & maximum \\
\hline $\min$ & minimum \\
\hline
\end{tabular}




\section{References}

1. Omri, A.; Orfi, J.; Nasrallah, S.B. Natural convection effects in solar stills. Desalination 2005, 183, $173-178$. [CrossRef]

2. Rashidi, S.; Akar, S.; Bovand, M.; Ellahi, R. Volume of fluid model to simulate the nanofluid flow and entropy generation in a single slope solar still. Renew. Eng. 2018, 115, 400-410. [CrossRef]

3. Fusegi, T.; Hyun, J.M.; Kuwahara, K.; Farouk, B. A numerical study of three dimensional natural convection in a differentially heated Cubical enclosure. Int. J. Heat Mass Transf. 1991, 34, 1543-1557. [CrossRef]

4. Tzeng, S.C.; Liou, J.H.; Jou, R.Y. Numerical simulation-aided parametric analysis of natural convection in a roof of triangular enclosures. Heat Transf. Eng. 2005, 26, 69-79. [CrossRef]

5. Chen, Q.; Wang, M.; Pan, N.; Guo, Z.-Y. Optimization principles for convective heat transfer. Energy 2009, 34, 1199-1206. [CrossRef]

6. Esfahani, J.A.; Akbarzadeh, M.; Rashidi, S.; Rosen, M.A.; Ellahi, R. Influences of wavy wall and nanoparticles on entropy generation in a plate heat exchanger. Int. J. Heat Mass Transf. 2017, 109, 1162-1171. [CrossRef]

7. Webb, R.L.; Kim, N.Y. Enhanced Heat Transfer; Taylor and Francis: New York, NY, USA, 2005.

8. Incropera, F.P.; De Witt, D.P. Fundamentals of Heat and Mass Transfer; John Wiley \& Sons, Inc.: New York, NY, USA, 1985.

9. Xuan, Y.; Li, Q. Investigation on convective heat transfer and flow features of nanofluids. J. Heat Transf. 2003, 125, 151-155.

10. Safaei, M.R.; Ahmadi, G.; Goodarzi, M.S.; Safdari Shadloo, M.; Goshayeshi, H.R.; Dahari, M. Heat transfer and pressure drop in fully developed turbulent flows of grapheme nanoplatelets-silver/water nanofluids. Fluids 2016, 1, 20. [CrossRef]

11. Safaei, M.R.; Ahmadi, G.; Goodarzi, M.S.; Kamyar, A.; Kazi, S.N. Boundary layer flow and heat transfer of FMWCNT/water nanofluids over a flat plate. Fluids 2016, 1, 31. [CrossRef]

12. Shirvan, K.M.; Mamourian, M.; Mirzakhanlari, S.; Ellahi, R. Numerical Investigation of Heat Exchanger Effectiveness in a Double Pipe Heat Exchanger Filled With Nanofluid: A Sensitivity Analysis by Response Surface Methodology. Powder Technol. 2017, 313, 99-111. [CrossRef]

13. Ho, C.J.; Chung, Y.N.; Lai, C.-M. Thermal performance of $\mathrm{Al}_{2} \mathrm{O}_{3}$ /water nanofluid in a natural Circulation loop with a mini-channel heat sink and heat source. Energy Convers. Manag. 2014, 87, 848-858. [CrossRef]

14. Kang, Z.; Wang, L. Effect of thermal-electric cross coupling on heat transport in nanofluids. Energies 2017, 10, 123. [CrossRef]

15. Asirvatham, L.G.; Vishal, N.; Gangatharan, S.K.; Lal, D.M. Experimental study on forced convective Heat transfer with low volume fraction of $\mathrm{CuO} /$ water nanofluid. Energies 2009, 2, 97-119. [CrossRef]

16. Patil, M.S.; Kim, S.C.; Seo, J.-H.; Lee, M.-Y. Review of the thermo-physical properties and performance characteristics of a refrigeration system using refrigerant-based nanofluids. Energies 2016, 9, 22. [CrossRef]

17. Patil, M.S.; Seo, J.-H.; Kang, S.-J.; Lee, M.-Y. Review on synthesis, thermo-physical property, and heat transfer mechanism of nanofluids. Energies 2016, 9, 840. [CrossRef]

18. Khanafer, K.; Vafai, K.; Lightstone, M. Buoyancy-driven heat transfer enhancement in a two-dimensional enclosure utilizing nanofluids. Int. J. Heat Mass Transf. 2003, 46, 3639-3653. [CrossRef]

19. Oztop, H.F.; Abu-Nada, E. Numerical study of natural convection in partially heated rectangular enclosure filled with nanofluids. Int. J. Heat Fluid Flow 2008, 29, 1326-1336. [CrossRef]

20. Tiwari, R.K.; Das, M.K. Heat transfer augmentation in a two-sided lid-driven differentially heated square cavity utilizing nanofluids. Int. J. Heat Mass Transf. 2007, 50, 2002-2018. [CrossRef]

21. Aminossadati, S.M.; Ghasemi, B. Natural convection cooling of a localized heat source at the bottom of a nanofluid-filled enclosure. Eur. J. Mech. B/Fluids 2009, 28, 630-640. [CrossRef]

22. Mamourian, M.; Shirvan, K.M.; Ellahi, R.; Rahimi, A.B. Optimization of mixed convection heat transfer with entropy generation in a wavy surface square Lid-Driven cavity by means of Taguchi approach. Int. J. Heat Mass Transf. 2016, 120, 544-554. [CrossRef]

23. Kim, J.; Kang, Y.T.; Choi, C.K. Analysis of convective instability and heat characteristics of nanofluids. Phys. Fluids 2004, 16, 2395-2401. [CrossRef]

24. Hwang, K.S.; Lee, J.H.; Jang, S.P. Buoyancy-driven heat transfer of water-based $\mathrm{Al}_{2} \mathrm{O}_{3}$ nanofluids in a rectangular cavity. Int. J. Heat Mass Transf. 2007, 50, 4003-4010. [CrossRef] 
25. Santra, A.K.; Sen, S.; Chakraborty, N. Study of heat transfer characteristics of copper-water nanofluid in a differentially heated square cavity with different viscosity models. J. Enhanc. Heat Transf. 2008, 15, 273-287. [CrossRef]

26. Ghanbarpour, M.; Nikkam, N.; Khodabandeh, R.; Toprak, M.S. Thermal performance of inclined screen mesh heat pipes using silver nanofluids. Int. Commum. Heat Mass Transf. 2015, 67, 14-20. [CrossRef]

27. Abu-Nada, E.; Chamkha, A.J. Effect of nanofluid variable properties on natural convection in enclosures filled with a CuO-EG-Water nanofluid. Int. J. Therm. Sci. 2010, 49, 2339-2352. [CrossRef]

28. Putra, N.; Roetzel, W.; Das, S.K. Natural convection of nanofluids. Heat Mass Transf. 2003, 39, 775-784. [CrossRef]

29. Wen, D.; Ding, Y. Natural convective heat transfer of suspensions of titanium dioxide nanoparticles (nanofluids). IEEE Trans. Nanotechnol. 2006, 5, 220-227.

30. Rahman, M.M.; Saha, S.; Mojumder, S.; Mekhilef, S.; Saidur, R. Numerical Simulation of Unsteady Heat Transfer in a Half Moon Shape Enclosure with Variable Thermal Boundary Condition for Different Nanofluids. Numer. Heat Transf. Part B Fundam. 2014, 65, 282-301. [CrossRef]

31. Ho, C.J.; Chen, M.W.; Li, Z.W. Numerical simulation of natural convection of nanofluid in a square enclosure: Effects due to uncertainties of viscosity and thermal conductivity. Int. J. Heat Mass Transf. 2008, 51, 4506-4516. [CrossRef]

32. Rahman, M.M.; Billah, M.M.; Hasanuzzaman, M.; Saidur, R.; Rahim, N.A. Heat transfer enhancement of nanofluids in a lid-driven square enclosure. Numer. Heat Transf. Part A Appl. 2012, 62, 973-991. [CrossRef]

33. Abu-Nada, E.; Oztop, H.F. Effects of inclination angle on natural convection in enclosures filled with CuO-water nanofluid. Int. J. Heat Fluid Flow 2009, 30, 669-678. [CrossRef]

34. Kahveci, K. Buoyancy driven heat transfer of nanofluids in a tilted enclosure. J. Heat Transf. 2010, 132, 62-74. [CrossRef]

35. Shirvan, K.M.; Ellahi, R.; Mamourian, M.; Moghiman, M. Effect of Wavy Surface Characteristics on Heat Transfer in a Wavy Square Cavity Filled with Nanofluid. Int. J. Heat Mass Transf. 2017, 107, 1110-1118. [CrossRef]

36. Lin, K.C.; Violi, A. Natural convection heat transfer of nanofluids in a vertical cavity: Effects of non-uniform particle diameter and temperature on thermal conductivity. Int. J. Heat Fluid Flow 2010, 31, $236-245$. [CrossRef]

37. Abu-Nada, E.; Masoud, Z.; Oztop, H.F.; Campo, A. Effect of nanofluid variable properties on natural convection in enclosures. Int. J. Therm. Sci. 2010, 49, 479-491. [CrossRef]

38. Jou, R.-Y.; Tzeng, S.C. Numerical research of natural convective heat transfer enhancement filled with nanofluids in rectangular enclosures. Int. Commun. Heat Mass Transf. 2006, 33, 727-736. [CrossRef]

39. Yu, Z. T.; Xu, X.; Hu, Y.C.; Fan, L.-W.; Cen, K.-F. Numerical study of transient buoyancy-driven convective heat transfer of water-based nanofluids in a bottom-heated isosceles triangular enclosure. Int. J. Heat Mass Transf. 2011, 54, 526-532. [CrossRef]

40. Rahman, M.M.; Öztop, H.F.; Ahsan, A.; Saidur, R.; Al-Salem, K.; Rahim, N.A. Laminar mixed convection in inclined triangular enclosures filled with water based Cu nanofluid. Ind. Eng. Chem. Res. 2012, 51, 4090-4100. [CrossRef]

41. Rahman, M.M.; Billah, M.M.; Rahman, A.T.M.M.; Kalam, M.A.; Ahsan, A. Numerical investigation of heat transfer enhancement of nanofluids in an inclined lid-driven triangular enclosure. Int. Commun. Heat Mass Transf. 2011, 38, 1360-1367. [CrossRef]

42. Billah, M.M.; Rahman, M.M.; Razzak, M.A.; Saidur, R.; Mekhilef, S. Unsteady buoyancy-driven heat transfer enhancement of nanofluids in an inclined triangular enclosure. Int. Commun. Heat Mass Transf. 2013, 49, 115-127. [CrossRef]

43. Rahman, M.M.; Saidur, R.; Mekhilef, S.; Uddin, M.B.; Ahsan, A. Double-diffusive buoyancy induced flow in a triangular cavity with corrugated bottom wall: Effects of geometrical parameters. Int. Commun. Heat Mass Transf. 2013, 45, 64-74. [CrossRef]

44. Sheremet, M.A.; Pop, I.; Shenoy, A. Unsteady free convection in a porous open wavy cavity filled with a nanofluid using Buongiorno's mathematical model. Int. Commun. Heat Mass Transf. 2015, 67, 66-72. [CrossRef] 
45. Rahman, M.M.; Öztop, H.F.; Steele, M.; Naim, A.G.; Al-Salem, K.; Ibrahim, T.A. Unsteady natural convection and statistical analysis in a CNT-water filled cavity with non-isothermal heating. Int. Commun. Heat Mass Transf. 2015, 64, 50-60. [CrossRef]

46. Wu, W.-T.; Massoudi, M.; Yan, H. Heat Transfer and Flow of Nanofluids in a Y-Type Intersection Channel with Multiple Pulsations: A Numerical Study. Energies 2017, 10, 492. [CrossRef]

47. Rashidi, S.; Esfahani, J.A.; Ellahi, R. Convective heat transfer and particle motion in an obstructed duct with two side-by-side obstacles by means of DPM model. Appl. Sci. 2017, 7, 431. [CrossRef]

48. Sheikholeslami, M.; Zia, Q.M.Z.; Ellahi, R. Influence of induced magnetic field on free convection of nanofluid considering Koo-Kleinstreuer (KKL) correlation. Appl. Sci. 2016, 6, 324. [CrossRef]

49. Ahmed, S.E.; Mansour, M.A.; Hussein, A.K.; Sivasankaran, S. Mixed convection from a discrete heat source in enclosures with two adjacent moving walls and filled with micropolar nanofluids. Eng. Sci. Technol. 2016, 19, 364-376. [CrossRef]

50. Brinkman, H.C. The viscosity of concentrated suspensions and solutions. J. Cryst. Growth 1952, 20. [CrossRef]

51. Wasp, F.J. Solid-Liquid Slurry Pipeline Transportation; Trans Tech Publications: Berlin, Germany, 1977.

52. Batchelor, G.K. An Introduction to Fluid Dynamics; Cambridge University Press: London, UK, 1993.

(C) 2017 by the authors. Licensee MDPI, Basel, Switzerland. This article is an open access article distributed under the terms and conditions of the Creative Commons Attribution (CC BY) license (http://creativecommons.org/licenses/by/4.0/). 